\title{
Injury to currants during mechanical harvesting and subsequent fungal infection
}

\author{
Risto TAHVONEN \\ Department of Plant Pathology, University of Helsinki, 00710 Helsinki 71, \\ Finland
}

\begin{abstract}
Mechanical harvesting did not cause significant damage to blackcurrants. Redcurrants suffered extensive injuries, which gave rise to dieback. In addition to mechanical injuries, the pathogen Botrytis cinerea Pers. aggravated bieback of the branches, and severely inhibited healing of the wounds. In wounds on both red- and blackcurrants, the commonest fungus was Alternaria tenuis auct. This fungus did not inhibit healing of the wounds, indeed it appeared to reduce the incidence of $B$. cinerea wound infection. The wounds contained 19 other fungal species and genera of no pathogenic importance. In a colder-than-average autumn, $B$. cinerea infection was more severe, and dieback during the subsequent season more extensive than usual. A methyl thiophanate application made in a cold autumn after harvesting reduced the incidence of $B$. cinerea in wounds, and little dieback resulted the following year. In mild autumns maneb and dichlofluanid reduced dieback, too. When the harvesting was followed by a cold autumn, mechanical harvesting reduced the following year's yield compared with hand-picking.
\end{abstract}

\section{Introduction}

In recent years, the cultivation of red- and blackcurrants has expanded rapidly in Finland. Often, the plantations are designed for harvesting with a machine. Mechanical harvesting is something of an innovation, however, and little experience has been obtained from northern areas of cultivation. The first machine designed for commercial production only came onto the British market in 1971, and Finland purchased her first currant harvester in 1975 (HYTÖNEN et al. 1978).

In more southern areas of cultivation, practical experience has been obtained in the mechanical harvesting of currants, mainly blackcurrants. The findings of other countries cannot be directly applied to Finnish conditions, since the time from harvesting to termination of the growing season is shorter than, and the habit of growth of northerly adapted varieties as well as their photoperiodic response is different from in England or Denmark. One source of concern is the ease with which fungal infections might arise as a consequence of mechanical harvesting, since fungi have been observed to cause dieback on 
currant branches in Finland, even without mechanical harvesting (SALONEN 1975).

In 1976, a project sponsored by the Finnish National Fund for Research and Development, on the mechanical harvesting of currants was started, in which the Work Efficiency Association, the University of Helsinki Department of Plant Pathology, the Association of Fruit Growers and three firms of the fruit refining industry have partificated. The aim of the study described below was to define the significance of injuries caused in Finland by mechanical currant harvesters and by the resulting fungal infection, and to determine the efficacy of disease control. As far as we are aware, no investigation of this type has been made previously.

\section{Material and methods}

The bushes were picked with a Pattenden Straddle Harvester. Redcurrant trials were made on two farms at Puumala, east Finland, and blackcurrant trials at Pohjankuru, southwest Finland, and at Ämmänsaari, north Finland. In the redcurrant trials, 3-4 year old bushes of Rondom and 15 year old bushes of Red Dutch were used. The blackcurrant varieties used were Öjebyn and Roodknop in southwest Finland, and Öjebyn and Erkheikki in north Finland. In addition, trials in which injuries were deliberately inflicted by hand were made on Öjebyn and on Brödtorp in Viikki, south Finland. Since the bushes were of different ages, no meanigful comparison could be made between the redcurrant varieties.

In southwest Finland, the bushes were harvested on August 16th, 1976 and on August 18th, 1977, in east Finland on August 24th, 1976 and August 23rd, 1977 and in north Finland on September 1st, 1976 and September 6th, 1977. The injury treatments were made at Viikki on August 20th, 1976.

After harvesting, redcurrants var. Rondom and blackcurrants var. Öjebyn (in southwest Finland) were sprayed with the fungicides copper oxychloride (Kupari 2), maneb (Maneba), methyl thiophanate (Topsin M) and dichlofluanid (Euparen) using the concentrations recommended for the control of wound infecting fungi.

Injuries incurred by the bushes were marked with plastic tags at the rate of $60 /$ treatment to facilitate and ensure adequate sampling at a later stage. After harvesting, injury samples were taken during October, May and July for laboratory studies. The yield for the year following mechanical harvesting was determined on $4 \times 5$ bushes. In addition, the yield of machinapicked bushes was compared with that of hand- and baton-picked bushes. The sampling of branches from the bushes must have influenced yields in some measure, and this bias will appear in the yield differences with respect to handpicked bushes. During the second year of the trial, determinations of fungicide residues were made at the State Agricultural Chemistry Department. In the following season, observational data on dieback were collected. For the estimation of dieback frequency, scores were allocated of 1 for sideshoots, 2 for main shoots, 2 for branches with dieback and 1 for stunted growth-rate. 
Fungi which had infected wounds were transferred to a maize agar medium (Difco) for microscopic identification. The injured branch was surfacesterilised by rinsing with $96 \%$ alcohol. The undamaged surface of the bark was removed both above and below the injury to revael the extent of damage caused by the fungus (Fig. 2) and to allow transfer of a sample to the nutrient medium. In additon, a July sampling was used for stereomictoscopic determination of Botrytis cinerea and Alternaria tenuis, and for the assessment of the healing of wounds on a $0-3$ scale. A total of 1367 injured samples of blackcurrant and 814 of redcurrant was examined. During the first sampling of the first year of the trial, isolates were made of fungi on the outside of the surface-sterilised wound region.

During the second year of the trial, a pathogenicity test was made on Botrytis cinerea by placing a piece of nutrient medium with the growing fungus on a mechanically injured redcurrant branch. A piece of the nutrient medium only was placed on control branches. After inoculation, the wounds were sealed with tape for two weeks.

After harvesting, temperatures were considerably lower during the first year of the trial than during the second. In east Finland, the temperature fell towards and below zero at the end of September in 1976, but not until mid-November in 1977 (Fig. 6). In north Finland sub-zero conditions set in one month after harvesting in both seasons. During the first trial year, rainfall was normal, while the second season was exceptionally wet.

\section{Results}

Injury to the bushes

Mechanical harvesting caused more serious injury to redcurrant than to blackcurrant bushes.

On old, unpruned redcurrant bushes, every branch suffered one or more injuries. Mechanical harvesting in three successive years rendered the bushes nearly barren. On younger, 3-4 year old bushes, the injuries appeared as small, grazed areas of bark (Fig. 1 a) or as torn sideshoots. Bark injuries were to be found on $30-70 \%$ of the branches (Rondom suffered less damage than Red Dutch).

On blackcurrants, mechanical harvesting caused only slight damage. On average, only $1-3$ grazing wounds or torn side-shoots appeared on fullygrown, 3-5 year old bushes. Because of its more erect growth, habit and lower degree of branching, the variety Roodknop suffered less damage than Öjebyn.

\section{Fungi infecting the wounds}

The fungus most frequently found infecting bark-wounds was Alternaria tenuis auct., which after grows within the bark and into the underlying wood. This resulted in a darkening of the green part of the stem. A year after in injury, the fungus was seldom to be found within the bark. During the first year of the study, when fungi entering the surface of the wounds were examined, A. tenuis had appeared in nearly every wound by the autumn. Both in redand blackcurrants, this fungus could be observed with a stereomicroscope in 


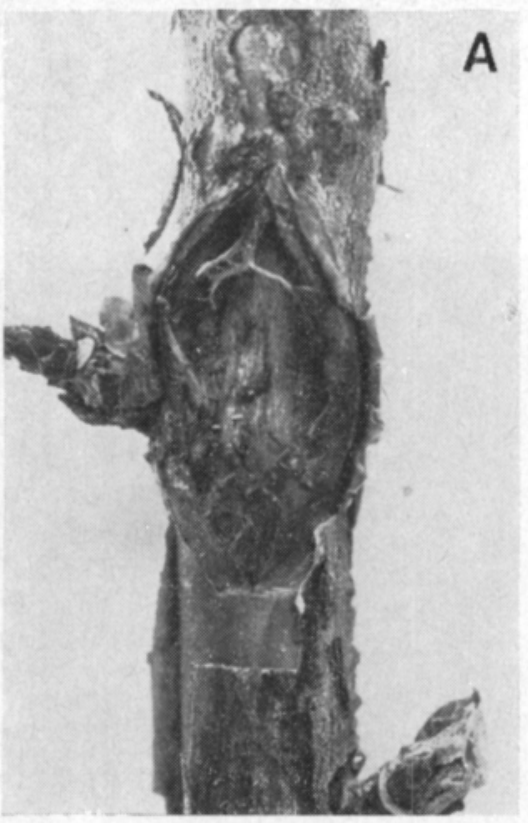

Fig. 1. Typical harvesting injuries on redcurrant (a)

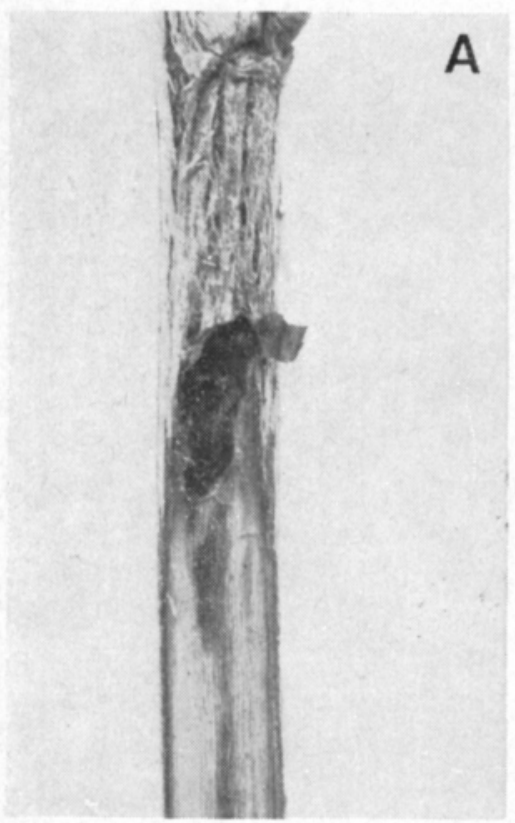

Fig. 2 a. Harmless discoloration of the bark from the wound downwards, caused by Alternaria tenuis,

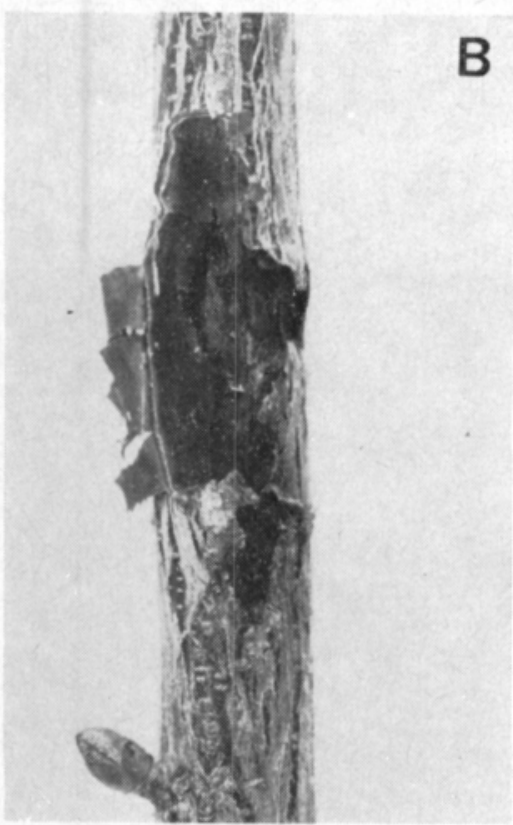

and blackcurrant (b).

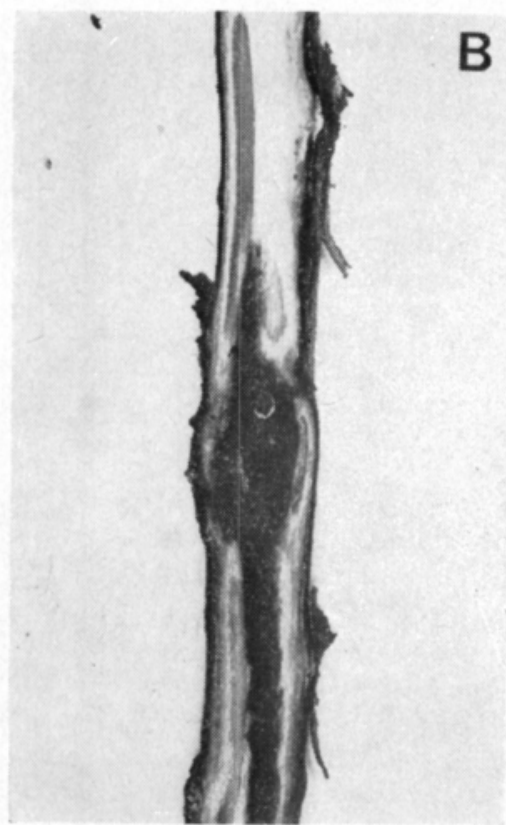

$2 \mathrm{~b}$, pronounced darkening of the bark caused by Botrytis cinerea. 
every injury examined a year after picking. A. tenuis did not appear to inhibit or prevent the growth of wound callus tissues.

Botrytis cinerea Pers. was found in wounds more frequently in red- than in blackcurrants (Table 1). In branches infected with this fungus, the green bark of the shoot turned brown the same autumn (Fig. 2 b). The following summer, conidiophores of the fungus developed, and sometimes sclerotia appeared in the wounds. When the fungus grew within the bark, large clusters of conidiophores broke through the bark (Fig. 4). The infected bark region swelled strongly during damp weather.

Table 1. Proportions of Botrytis cinerea in mechanical harvesting injuries in 1976 and 1977.

\begin{tabular}{|c|c|c|}
\hline & \multicolumn{2}{|r|}{ Year of harvest } \\
\hline & 1976 & 1977 \\
\hline & B. cinerea & $\%$ in injuries 11 months after picking \\
\hline Redcurrant .......................... & 42.6 & 30.2 \\
\hline Blackcurrant ........................ & 2.4 & 25.5 \\
\hline
\end{tabular}

In redcurrants, the content of Botrytis cinerea found during the third examination in the first trial year was $60 \%$ in the control (Table 2). Wounds infected by this fungus healed very slowly compared with other wounds (Fig. 3, Tables 2 and 3). B. cinerea could be found in most wounds on dead branches. During the first year, when grey mould was widespread on redcurrants, a methyl thiophanate treatment after harvesting significantly reduced the proportion of fungi in bark wounds (Table 2). In branches killed by $B$. cinerea,

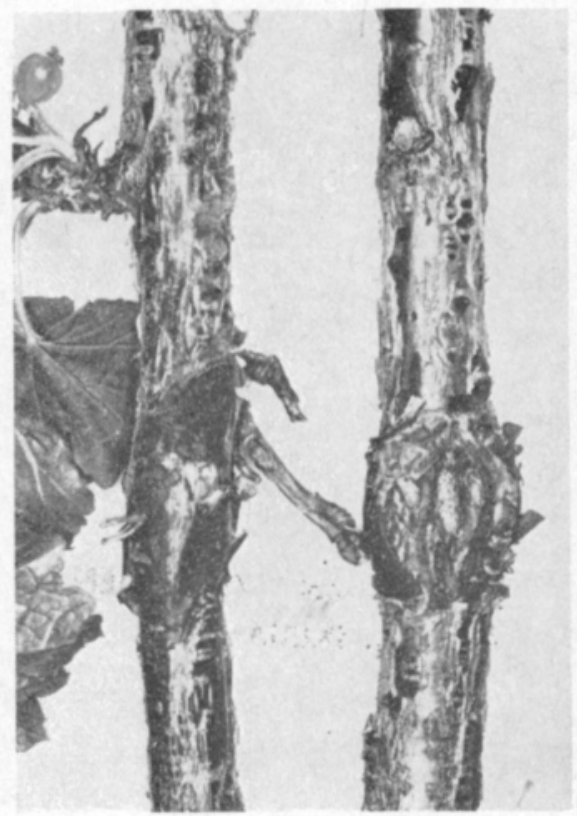

Fig. 3. A normally healed injury and one with poor cambial formation, infected with Botrytis cinerea.

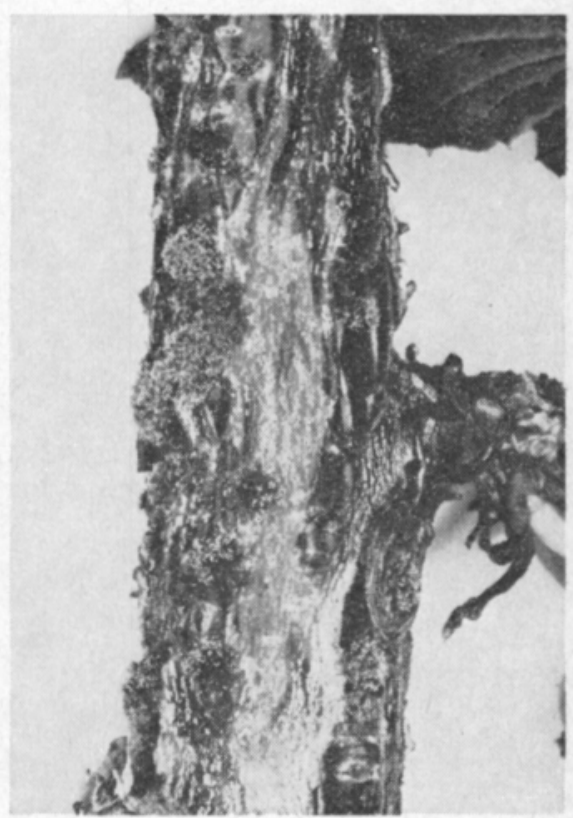

Fig. 4. Conidiophores of Botrytis cinerea extruding from the bark. 
Table 2. The effects of various fungicide applications made after mechanical harvesting on the dieback of branches, the healing of wounds and contents of Botrytis cinerea in injuries to redcurrant. Harvesting in 1976, and observations made in July 1977.

\begin{tabular}{|c|c|c|c|c|c|c|}
\hline & Control & $\begin{array}{c}\text { Copper } \\
\text { oxy- } \\
\text { chloride }\end{array}$ & $\begin{array}{r}\text { Fun } \\
\text { Maneb }\end{array}$ & $\begin{array}{l}\text { gicide } \\
\text { Methyl } \\
\text { thio- } \\
\text { phanate }\end{array}$ & $\begin{array}{l}\text { Dichlo- } \\
\text { fluanid }\end{array}$ & $\overline{\mathrm{x}}$ \\
\hline Branches killed as $\%$ of injured & 33 & 42 & 44 & 14 & 47 & 39 \\
\hline $\begin{array}{l}\text { B. cinerea } \% \text { in branches with } \\
\text { dieback }\end{array}$ & 100 & 100 & 63 & 50 & 89 & 75 \\
\hline B. cinerea $\%$ in injured branches & 60 & 50 & 39 & 14 & 50 & 43 \\
\hline $\begin{array}{l}\text { Regrowth of cambium in branches } \\
\text { infected by } B \text {. cinerea }(0-3) \ldots \ldots\end{array}$ & 1.4 & 1.0 & 1.7 & 2.0 & 0.6 & 1.25 \\
\hline $\begin{array}{l}\text { Regrowth of cambium in branches } \\
\text { not infected by } B \text {. cinerea }(0-3)\end{array}$ & 3.0 & 3.0 & 2.9 & 2.8 & 2.6 & 2.8 \\
\hline
\end{tabular}

Table 3. The effects of Botrytis cinerea on the healing of injuries caused in harvesting redand blackcurrants. Harvesting in 1977, and observations made in July 1978.

\begin{tabular}{ccc}
\hline & $\begin{array}{c}\text { Injuries infected } \\
\text { with } B \text {. cinerea }\end{array}$ & $\begin{array}{c}\text { Injuries not infected } \\
\text { with } B \text {. cinerea }\end{array}$ \\
\hline & Regrowth of cambium $0-3$ \\
Redcurrant $\ldots \ldots \ldots . .$. & 2.2 & 2.6 \\
Blackcurrant ......... & 1.0 & 2.2 \\
\hline
\end{tabular}

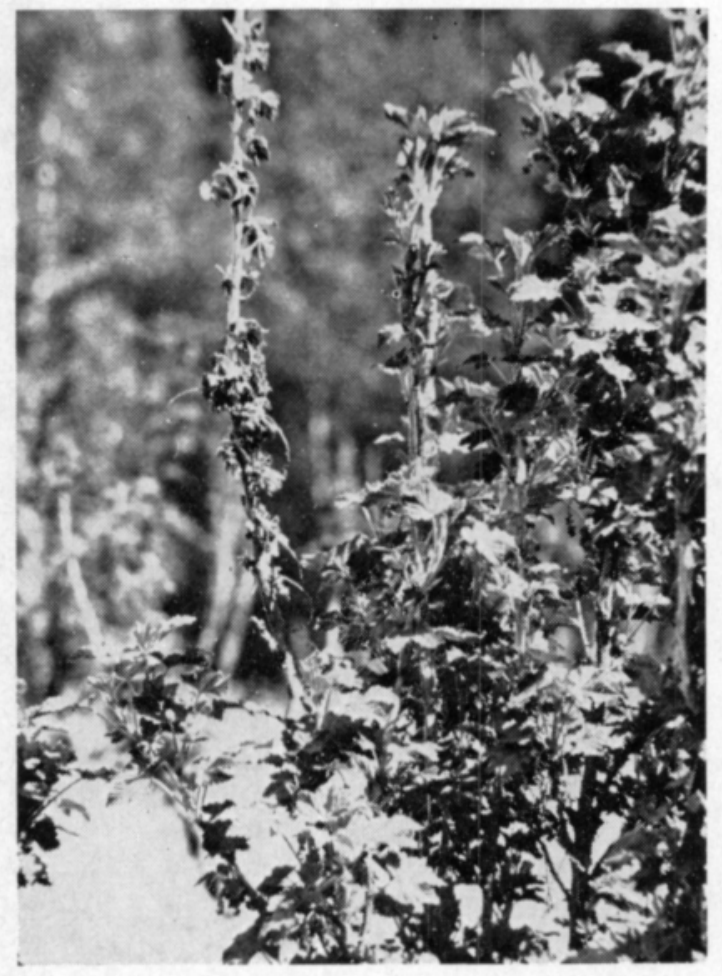

Fig. 5. Dieback of a branch resulting from Botrytis cinerea attack. 


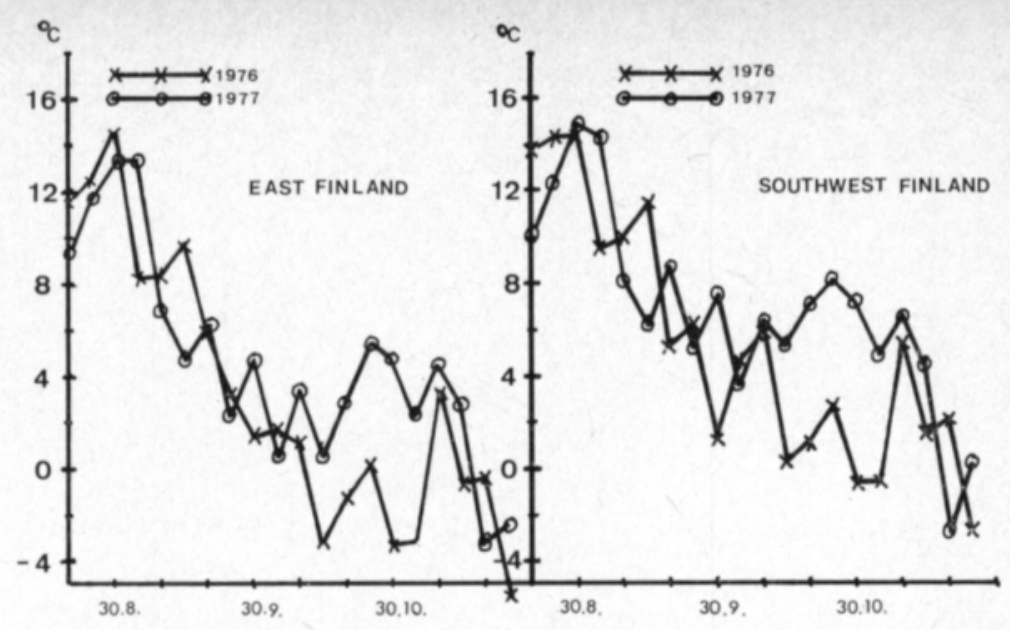

Fig. 6. Mean temperatures for pentads between August 19th and November 26th, 1977 and 1978, for Eeast and Southwest Finland.

Nectria cinnabarina (Tode) Fr. appeatred the following year. It was found in pathogenicity tests that grey mould caused dieback of the branches the spring and summer after infection (Fig. 5).

Several other species of fungus were found in bark injuries of red-and blackcurrants, but which on account of their low proportion or their saprophytic nature probably do not affect the healing of wounds or dieback of the branches. In addition th those already mentioned, the following fungi were identified:

\section{Fungus}

Aureobasidium pullulans (de Bary) Arnaud

Chaetosphaeria myriocarpa (Fr.) Booth

Cladosporium spp.

Coniothyrium sp.

Epicoccum purpurascens Ehrenb. ex Schlecht.

Fusarium spp.

F. avenaceum (Corda ex Fr.) Sacc.

F. culmorum (W. G. Smith) Sacc.

F. oxysporum Schlecht.

$F$. redolens Wollenw.

F. semitectum Berk. \& Rav.

Geniculosporium serpens (Chesters \& Greenhalgh

Hormiscium sp.

Penicillium spp.

Phoma sp.

Phoma herbarum Westd

Rhizoctonia sp.

Stemphylium consortiale (Thum.) Groves \& Skolko

Trichoderma viride Pers. ex Fr.

Tubercularia sp.

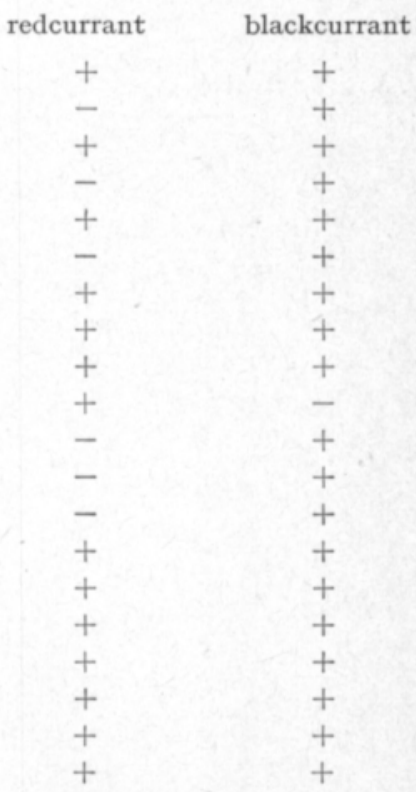

The proportions of Cladosporium, F. avenaceum and Penicillium comprised about $5 \%$ of total fungi in the samples of branches, and that of other fungi was less than $1 \%$. In north Finland, the wounds were significantly less infected by fungi than in south Finland. 


\section{Dieback of the branches}

In blackcurrants, mechanical harvesting did not cause appreciable dieback of the branches. In most cases, the bark layer had been damaged right around the dead branches, which had prevented the transportation of metabolites to the upper parts of the branches, and caused them to dieback. No relation could be found between dieback of the branches and fungi infecting the wounds.

In redcurrants, dieback of the branches was widespread during the summer after mechanical harvesting. There was pronounced variation between seasons. In the first year of the trial, $39 \%$ of the bark injuries resulted in dieback, and in the second year less than $5 \%$. There was a clear relationship between the dieback of branches and the occurrence of B. cinerea in the wounds (Table 2). On young, 3-4 year old bushes the injuries were almost invariably of the type shown in Fig. 1 a, provided the operator of the machine had steered it precisely. Injuries of this type were often infected by $B$. cinerea. Of injuries infected by the fungus, $68 \%$ resulted in dieback before the following cropping season. Injuries associated with tearing did not result in dieback of the main stem. On young bushes, the bark was generally injured on one side of the stem, so that the ultimate cause of dieback was grey mould, but on old, stiffbranched bushes the injuries were usually so extensive, that entire branches died back partly as a result of mere bark wounds.

There were differences in rates of recovery between different years of the trial. During the first year, callus tissue did not start to form in the wounds until the following season. Only in the blackcurrant variety 'Brödtorp' could callus be found in wounds during the autumn of the injury. In the second trial year, callus had formed during the autumn after harvesting in both currant species. In north Finland, injuries started to heal for the most part during the season after harvesting.

An application of the fungicide methyl thiophanate given after harvesting reduced significantly dieback of the branches during the first trial year (Table 2). During the second trial year, all fungicide treatments except the copper compound reduced dieback of the branches (Table 4).

The fungicides had little effect on blackcurrants, since there was little dieback even without the fungicide.

\section{Yields and residues}

Both in red- and blackcrurrants, mechanical and baton harvesting in the first trial year reduced the next season's yield compared with handpicking

Table 4. The effects of various fungicides applied after mechanical harvesting in 1977 on dieback of redcurrant branches during the following year.

\begin{tabular}{lcccc}
\hline Control & $\begin{array}{c}\text { Copper } \\
\text { oxycloride }\end{array}$ & Maneb & $\begin{array}{c}\text { Methyl- } \\
\text { thiophanate }\end{array}$ & $\begin{array}{c}\text { Dichlo- } \\
\text { fluanid }\end{array}$ \\
\hline \multicolumn{6}{c}{ Dieback/40 bushes } \\
\hline 27.0 & 33.0 & 12.5 & 17.7 & 13.3 \\
\hline
\end{tabular}

$\mathrm{F}$ value $=6.97^{* *}, \mathrm{LSD}_{\mathrm{t}_{0.05} \%}=10.1$ 
Table 5. The effects of mechanical and baton harvesting in 1976 on red- and blackcurrant yields in 1977.

\begin{tabular}{lcccc}
\hline & $\begin{array}{c}\text { Hand- } \\
\text { picking } \\
1976\end{array}$ & $\begin{array}{c}\text { Baton } \\
\text { harvesting } \\
1976\end{array}$ & $\begin{array}{c}\text { Mechanical } \\
\text { harvesting } \\
1976\end{array}$ \\
\hline & & & Relative yield (kg/bush) in 1977 \\
Blackcurrant Öjebyn, South-Finland ......... & $100(2.1)$ & 63 & 66 \\
Blackcurrant Erkheikki, North Finland ..... & $100(1.4)$ & - & 91 \\
Redcurrant Rondom, East Finland ........... & $100(1.7)$ & 72 & 61 \\
Redcurrant Red Dutch, East Finland ........ & $100(1.5)$ & - & 63 \\
\hline
\end{tabular}

Table 6. The effects of various fungicides applied after mechanical harvesting on currant yields in the following year (1978).

\begin{tabular}{|c|c|c|c|c|}
\hline Control & $\begin{array}{c}\text { Copper } \\
\text { oxychloride }\end{array}$ & Maneb & $\begin{array}{c}\text { Methyl- } \\
\text { thiophanate }\end{array}$ & $\begin{array}{l}\text { Dichlo- } \\
\text { fluanid }\end{array}$ \\
\hline \multirow{3}{*}{1.14} & , & $\begin{array}{c}\text { kg/bush } \\
\text { Redcurrant }\end{array}$ & & \\
\hline & 1.41 & 1.25 & 1.28 & 1.16 \\
\hline & & Blackcurrant & & \\
\hline 0.66 & 0.46 & 0.52 & 0.66 & 0.72 \\
\hline
\end{tabular}

(Table 5). There was little yield difference during the second trial year (Table 6). After application of the Maneb compound, a $1 \mathrm{ppm}$ residue was found in the yield of the following season. The other preparations did not give rise to residues.

\section{Discussion}

In Finland, mechanical harvesting does not cause such extensive damage to blackcurrants that the health of the bushes is affected to any extent. Wounds do not become infected with pathogenic fungi, but generally heal well during the following season at the latest.

In redcurrants the trials demonstrate that mechanical harvesting involves a considerable risk of the bushes being infected. Injuries to old, stiffly branched bushes are frequently so extensive that the branches die back purely as a result of the injuries. In young bushes better suited to mechanical harvesting, the wounds heal readily, provided they do not become infected with grey mould. Some studies indicate that Botrytis cinerea is one of the chief causes of dieback in redcurrants (Schmidle 1958, Schmidle 1960, Bondarenko 1967, SALONEN 1975).

There exists a very prevalent notion that the fungus Nectria cinnabarina is a common and important cause of dieback in currant bushes (KоTTE 1958). The present trials demonstrate that the injured branches are first invaded by Botrytis cinerea, the agent of dieback, and only subsequently do the branches 
become secondarily infected by coral fungus. The conidial stage Tubercularia of Nectria could be isolated from the wounds only very infrequently. This observation agrees with that of Schmides (1958) in his investigation on the dieback of branches.

In order that mechanical harvesting succeed, the control of grey mould must be given first priority. For grey mould infection to start, there must be a mechanical graze or similar route of infection into the plant. The redcurrant is resistant to grey mould during the growing season, and its resistance is highest at the time of ripening (SchmideE 1960). If the period after harvesting is warm, enabling callus tissues to form, the fungus cannot enter wounds. It appears extremely likely from the results of the two trial years that bark injuries are highly susceptible to grey mould infection in years when mean September and October temperatures are near or only slightly above freezing. At this time, redcurrants are susceptible to the disease (Schmide 1958). According to the observations made in such seasons the plant does not have time to form protective tissues before the onset of low temperatures, whereas grey mould can still grow at near-freezing temperatures (JARvis 1977). The raininess of the autumn apparently does not affect susceptibility to infection, as there is enough moisture inside the woody tissues for infection to occur even in dry autumns.

It may be possible to restrict grey mould infection and thus reduce the dieback it causes by spraying with a fungicide after harvesting. In warm autumns, the fungicide treatment appears to delay slightly the onset of infection, which gives the tissues time to heal somewhat and resist infection. In a cold autumn, when the wounds do not have time to heal before the end of the growing season, a non-specific fungicide offers no protection against infection. Apparently the effects of the fungicide wear off too quickly to prevent the spread of mould. However, when the systemic fungicide methyl thiophanate was applied at a similar time, good control was obtained. The active period of this substance in the wounds is probably no longer than for other substances, though. Wounds on currant stems are almost invariably invaded by Alternaria tenuis, upon which methyl thiophanate has no effect whatever. When a selecttive fungicide is used, the wounds are infected almost solely by Alternaria tenuis, which prevents grey mould from invading the wounds after the effects of the fungicide have worn off. Nevertheless, for clarificantion of this phenomenon further investigations are needed. A non-pathogenic isolate of an Alternaria sp. reduced drastically the incidence of tobacco brown spot disease caused by $A$. alternata (Fries) Keisler (SPURR 1977), which also indicates possibilities of using this fungus in biological control.

\section{Acknowledgements}

The Finnish National Fund for Research and Development has contributed to financing research equipment and staff for this study. Mr. Toivo Hytönen, M.Sc., Mr. Erkki Kemppainen and Miss Taina Kantokorpi have carried out much of the field and laboratory work, for which I wish to extend my gratitude. Similarly Prof. Eeva Tapio, Head of the Plant Pathology Department and the organising committee for the research project on the mechanical harvesting of currants have provided invaluable assistance through their support and their opinions regarding the execution of this study. 
Boundarenko, A. I. 1967. Usyhanie steblei Smorodiny. Zaschch. Rast., Mosk. 12, 5: 39. (Ref. RAM 46: 3141).

JARVIS, W. R. 1977. Botryotinia and Botrytis species: taxonomy, physiology and pathogenicity. 195 p. Monograph 15.

Hytönen, T., Liskola, K. \& TAHVonen, R. 1978. Ennakkotietoja herukan koneellisen korjuun soveltuvuudesta Suomen oloihin. 33 p. Suomen itsenäisyyden juhlavuoden 1967 rahasto.

Kotre, W. 1958. Krankheiten und Schädlinge im Obstbau. 519 p. Berlin und Hamburg. SAlONEN, A. 1975. Herukan oksien lakastumistaudista. Hedelmä ja marja 22: 79-80.

SchmidiLE, A. 1958. Ein Zweigsterben der Johannisbeere verursacht durch Botrytis cinerea Pers. ex Fr. Phytopath. Z. 33:117-126.

- 1960. Ein Zweigsterben der Johannisbeere, verursacht durch Botrytis cinerea Pers. ex Fr. II. Weitere Beobachtungen und Infektionsversuche an Roten und Schwarzen Johannisbeeren. Nachr. bl. Deut. Pfl. schutzd. 12: 151-154.

SPURR, H. W. 1977. Protective applications of nonpathogenic Alternaria sp. isolates for control of tobacco brown spot disease. Phytopath. 67: 128-132.

Ms received May 21, 1979.

\title{
SELOSTUS
}

\section{Koneellisen sadonkorjuun aiheuttamat vauriot herukoilla ja vaurioihin iskeytyvät sienet}

\author{
Risto TAHVONEN \\ Helsingin yliopiston kasvipatologian laitos, Viikki, 00710 Helsinki 71
}

Koneellisen sadonkorjuun aiheuttamia vaurioita ja niihin iskeytyviä sieniä tutkittiin mustaherukalla Lounais-Suomessa ja Pohjois-Suomessa ja punaherukalla Itä-Suomessa. Haavoihin iskeytyvien sienien torjumiseksi suoritettiin ruiskutuksia sadonkorjuun jälkeen eri aineilla,

Koneellinen sadonkorjuu ei aiheuttanut merkittävää haittaa mustaherukalle ja tästä syystä sadonkorjuun jälkeen suoritetut ruiskutukset olivat myös tarpeettomia.

Vanhoilla, jäykkäoksaisilla punaherukoilla koneellinen sadonkorjuu aiheutti pensaille niin suuria vaurioita, että pensaat tuhoutuivat lähes satoa tuottamattomiksi kolmen poimintavuoden jälkeen. Nuorilla pensailla oksiin syntyi pääosin vain kuorivaurioita ja sivuoksien repeämiä. Kuorivauriot parantuivat lämpimänä syksynä ja sitä seuraavana kesänä normaalisti, mutta kylmänä syksynä ja sitä seuraavana kesänä vaurioihin iskeytyi voimakkaasti yleinen harmaahome, joka aiheutti oksien kuihtumista noin kolmanneksen vaurioiden määrästä, joita syntyi $30-70 \%$ :iin oksista.

Vaurioihin iskeytyi erittäin runsaasti Alternaria tenuis auct., joka ei haitannut haavojen paranemista ja ei aiheuttanut oksien kuihtumista, mutta ilmeisesti vähensi tehokkaasti yleisen harmaahomeen iskeytymistä haavoihin. Botrytis cineres Pers., yleinen harmaahome oli yleinen haavasieni, joka esiintyi punaherukalla runsaampana kuin mustaherukalla. Kylmänä syksynä, jolloin vioitukset eivät ehtineet parantua kunnolla, sieni oli noin $60 \%$ :ssa haavoista ja lähes yksinomaan kuihtuneissa oksissa. Haavoihin iskeytyi suuri joukko muita sieniä, joilla ei kuitenkaan ollut merkitystä haavojen paranemiselle ja oksien kuihtumiselle.

Sadonkorjuun jälkeen suoritettu metyylitiofanaatti-ruiskutus (Topsin M) vähensi haavojen harmaahomerunsautta ja oksien kuihtumista kylmänä syksynä. Lämpöisenä syksynä myös manebi (Maneba) ja diklofluanidi (Euparen) vähensivät oksien kuihtumista.

Koneellinen sadonkorjuu alensi seuraavan vuoden satoa käsinpoimintaan verrattuna, kun sadonkorjuun jälkeinen syksy oli normaalia viileämpi. 